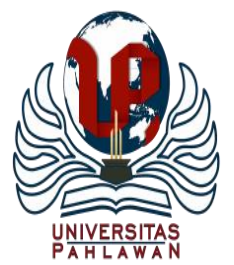

Edukatif : Jurnal Ilmu Pendidikan Volume 3 Nomor 5 Tahun 2021 Halm 1957 - 1970

EDUKATIF: JURNAL ILMU PENDIDIKAN

Research \& Learning in Education

https://edukatif.org/index.php/edukatif/index

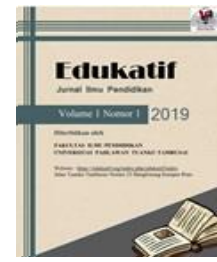

\title{
Pengembangan E-LKPD Berbasis Android dengan Model Pembelajaran Problem Based Learning (PBL) untuk Meningkatkan Berpikir Kritis Peserta Didik
}

\author{
Ika Melina Nur Fitriyah ${ }^{1 凶}$, Muhammad Abdul Ghofur ${ }^{2}$ \\ Universitas Negeri Surabaya, Indonesia ${ }^{1,2}$ \\ E-mail : $\underline{\text { ika.17080554014@mhs.unesa.ac.id }}{ }^{1}$, muhammadghofur@unesa.ac.id ${ }^{2}$
}

\begin{abstract}
Abstrak
Masalah pembelajaran ekonomi di SMA yaitu rendahnya dalam mengembangkan keterampilan berpikir kritis dan memecahkan masalah dengan tepat. Model problem based learrning digunakan untuk merangsang berpikir kritis dalam situasi berorientasi berbasis masalah.Tujuan penelitian ini yaitu untuk mengetahui peningkatan berpikir kritis peserta didik dengan menggunakan model pembelajaran PBL. Model pengembangan penelitian ini adalah model pengembangan 4D (Define, Design, Development, Disseminate). Desain penelitian menggunakan pretest-posttest control group design. Subjek penelitian sebanyak 36 peserta didik di SMA Negeri 1 Bangil. Hasil penelitian yaitu bahwa pada kelas eksperimen dengan penerapan model problem based learning mengalami kenaikan, dengan hasil uji gain score bahwa pada kelas eksperimen dalam kriteria sedang. sedangkan pada kelas kontrol juga mengalami kenaikan dalam berpikir kritis, dengan hasil uji gain score dalam kriteria rendah. Hasil respons siswa terhadap penggunaan E-LKPD ini dengan kriteria sangat baik. E-LKPD berbasis android diharapkan dapat mendorong siswa dalam memotivasi semangat dalam belajar.
\end{abstract}

Kata Kunci: Lembar Kerja Peserta Didik, Problem Based Learning, Berpikir Kritis.

\begin{abstract}
The problem of learning economics in high school is the low level of developing critical thinking skills and solving problems appropriately. The model is problem based learning used to stimulate critical thinking in problem-based oriented situations. The purpose of this study is to determine the improvement of thinking critical of students by using the PBL learning model. The development model of this research is a $4 D$ development model (Define, Design, Development, Disseminate). The research design used a pretest-posttest control group design. The research subjects were 36 students at SMA Negeri 1 Bangil. The result of the research is that the experimental class with the application of the model problem based learning has increased, with the test results gain score that the experimental class has moderate criteria. while the control class also experienced an increase in critical thinking, with the test results gain score in low criteria. The results of student responses to the use of E-LKPD with very good criteria.-based E-LKPD is Android expected to encourage students to motivate enthusiasm in learning.
\end{abstract}

Keywords: Student Activity Sheet, Problem Based Learning, Critical Thinking.

Copyright (c) 2021 Ika Melina Nur Fitriyah, Muhammad Abdul Ghofur

$\triangle$ Corresponding author

Email : ika.17080554014@mhs.unesa.ac.id

DOI : https://doi.org/10.31004/edukatif.v3i5.718

ISSN 2656-8063 (Media Cetak)

ISSN 2656-8071 (Media Online)

Edukatif : Jurnal Ilmu Pendidikan Vol 3 No 5 Tahun 2021 p-ISSN 2656-8063 e-ISSN 2656-8071 
1958 Pengembangan E-LKPD Berbasis Android dengan Model Pembelajaran Problem Based Learning (PBL) untuk Meningkatkan Berpikir Kritis Peserta Didik - Ika Melina Nur Fitriyah, Muhammad Abdul Ghofur DOI: https://doi.org/10.31004/edukatif.v3i5.718

\section{PENDAHULUAN}

Perkembangan Teknologi dan Informasi (TIK) saat ini mengalami perkembangan yang cukup pesat. Perkembangan tersebut memiliki dampak di berbagai bidang, terutama pada bidang pendidikan, dimana terus berkembangnya strategi dan pola dalam pembelajaran. TIK terus menciptakan terobosan baru dalam pembelajaran. Teknologi dapat memperluas kegiatan pembelajaran, terbukti saat ini sebagian pembelajaran sudah beralih dengan metode online yang tak terbatas dari sebelumnya yang hanya dilakukan di ruang kelas. Sehingga siswa dalam belajarnya bisa di lakukan secara mandiri, baik tanpa bantuan atau bimbingan dari gurunya di kelas ataupun di luar sekolah (Jumaat \& Tasir, 2014).

Pendidikan saat ini harus bisa menyesuaikan dengan adanya informasi yang mudah, didukung dengan teknologi yang ada dengan berpikir kritis. Menurut Fatriani \& Sukidjo (2018) berpikir kritis sendiri didefinsikan sebagai sebuah proses pemikiran dalam konsep keterampilan, mengaplikasi sebuah analisis, sintetis, mengevaluasi informasi dan generalisasi. Sedangkan menurut Patonah (2014) bahwa berpikir kritis merupakan kemampuan mentalitas sesorang yang dimilikinya dengan menggunakan kecerdasannya untuk menyelesaikan masalah yang dihadapi. Proses tersebut berhubungan dengan pola berpikir pada ranah kognitif untuk menciptakan suasana yang bermakna. Pada saat mengamati peserta didik diharapkan dapat menemukan pengetahuan baru dari pengalaman yang telah di dapat. Tahapan-tahapan tersebut ini akan mengubah pola pikir siswa. Namun pada kenyataannya dalam memperoleh informasi atau pengetahuan yang didapat, siswa cenderung melewati tahapan atau proses yang diterima.

Berdasarkan hasil pengamatan di sekolah bahwa siswa menggunakan aplikasi zoom meeting dalam proses pembelajaran saat pandemi. Namun ini menjadi kendala oleh peserta didik karena adanya keterbatasan jaringan internet disetiap tempat tinggal masing-masing, terlihat bahwa saat guru menjelaskan materi yang sedang berlangsung, masih ada siswa yang tiba-tiba keluar dari aplikasi dengan sendirinya. Selain itu masih ada siswa yang tidak menyalakan kamera, sehingga guru kesulitan memantau aktivitas yang dilakukan siswa saat proses belajar belangsung.

Saat guru menerangkan materi dengan metode daring, guru menggunakan beberapa aplikasi sebagai penunjang belajar agar terhubung antara guru dan siswa. pada saat mengorganisasi siswa biasanya guru menggunakan aplikasi whatsapp group, mulai dari mengabsen siswa dan membagikan materi yang akan dipelajari. hal ini juga berdampak pada media yang digunakan. Guru biasanya membagikan materi berupa emodul, buku paket, dan google classroom. Pada saat pembelajaran daring, guru menjelaskan materi dengan model belajar langsung yaitu fokus kepada guru dan dilanjut dengan memberikan latihan soal di buku, sehingga menyebabkan siswa dalam menyerap materi hanya sebatas menerima penjelasan dari guru dan kurang mengembangkan kemampuan berpikir kritis.

Media penunjang yang digunakan dalam pembelajaran sudah memanfaatkan teknologi. Hanya saja siswa belum sepenuhnya melatih dirinya dengan mencoba latihan soal secara mandiri untuk meningkatkan cara berpikir kritis. Selain itu, materi yang kompleks dan membutuhkan pemahaman yang lebih, tentunya akan membutuhkan waktu yang lama supaya peserta didik bisa memahami materi yang akan di pelajari. Pada situasi pandemi ini, jam pembelajaran pada mata pelajaran ekonomi menjadi berkurang, sehingga akan berdampak pada pemahaman dan cara berpikir peserta didik.

Untuk mengetahui tingkat berpikir kritis peserta didik, biasanya guru memberikan soal tes kepada siswa, sebagian besar peserta didik tidak bisa menjawab pertanyaan dengan tepat, mereka hanya bisa menjawab pertanyaan pada pengetahuan C1-C2 atau pemahaman konsep saja. Siswa belum bisa berpikir secara kritis saat dihadapkan dengan soal yang berbasis masalah pada dunia nyata, menganalisis peristiwa, dan memaknai kejadian serta menyediakan alternatif solusi yang sesuai dengan pernyataan soal yang tersedia. Sedangkan kompetensi dasar yang harus dicapai oleh peserta didik pada K.D 3.4 dan K.D 4.4 yaitu pada tahap 
1959 Pengembangan E-LKPD Berbasis Android dengan Model Pembelajaran Problem Based Learning (PBL) untuk Meningkatkan Berpikir Kritis Peserta Didik - Ika Melina Nur Fitriyah, Muhammad Abdul Ghofur DOI: https://doi.org/10.31004/edukatif.v3i5.718

tingkat analisis dan merumuskan gagasan dalam pemecahan masalah. Maka, dalam hal ini terdapat suatu permasalahan dalam belajar siswa terkait dengan cara berpikir kritis

Pada pelajaran ekonomi terutama pada materi Indeks harga dan Inflasi tersebut mencakup materi yang kompleks dan dibutuhkan pemahaman yang mendalam. Selain itu, juga terdapat hafalan yang berupa rumusrumus pada bagian indeks harga. Selanjutnya peserta didik hanya mengandalkan buku paket yang sudah disediakan oleh pihak sekolah sebagai sumber belajar mereka. Sumber belajar yang digunakan bersifat naratif, Namun buku mempunyai manfaat bagi pembacanya, karena sifat naratifnya ini akan menyebabkan peserta didik kesulitan untuk mengkonstruksi informasi-informasi yang ada di dalamnya, sehingga harus membutuhkan metode dalam menyelesaikan suatu masalah.

Untuk meminimalisir salah satu masalah tersebut, guru harus memberikan inovasi pembelajaran dan menggali kemampuan mengajar dengan merancang dan mengembangkan bahan ajar (Furman Shaharabani \& Yarden, 2019). Bahan ajar yang dikembangkan yaitu dengan menyediakan soal dengan ranah kognitif yang mampu mendukung siswa untuk berpikir secara kritis. Selain itu, bahan ajar tersebut di desain dengan memanfaatkan teknologi yang disertai materi, latihan soal, dan lembar kerja guna mendukung siswa dalam meningkatkan kemampuan berpikir kritis.

Metode tersebut kemudian dikemas dalam bahan ajar yang berupa e- LKPD yang memuat materi dan soal-soal yang dikemas dengan model pembelajaran problem based learning dengan memanfaatkan teknologi berupa mobile learning berbasis android. Pembelajaran dengan menggunaan mobile learning diharapkan akan berdampak positif kepada peserta didik, karena dalam proses belajar tidak dibatasi ruang kapan pun dan di mana pun (Warsita, 2018).

Model problem based learning adalah yaitu suatu pendekatan yang dimulai dengan memberikan suatu permasalahan dan diminta untuk menyelesaikan masalah (Siswono dalam Assegaff \& Sontani, 2016). Menurut Fatriani \& Sukidjo (2018) bahwa problem based learning dimulai dengan membentuk kelompokkelompok kecil yang bertujuan untuk pemecahan masalah pada dunia nyata dengan cara saling berdiskusi dan menemukan sebuah pengetahuan baru bersama. Pembelajaran dengan berbasis masalah siswa memiliki kebebasan untuk melakukan sebuah penyelidikan yang dilakukan baik di luar atau di dalam kelas. Setelah itu guru membantu siswa dalam menguraikan rencana pemecahan masalah dengan memberikan contoh-contoh secara sederhana untuk membantu menyelesaikan tugas-tugas agar bisa terselesaikan dengan baik.

Keterkaitan model pembelajaran problem based learning dengan berpikir kritis yaitu pada saat siswa dihadapkan dengan pemecahan masalah yang diberikan, maka siswa akan menggunakan berpikir mereka sebagai pengetahuan awal mereka dan hanya memberikan penjelasan secara sederhana. Kemudian pada saat siswa melakukan pengumpulan data, siswa biasanya mengumpulkan taktik sekaligus strategi untuk mendukung kemampuan berpikir kritis. Hasil dari analisis pemecahan masalah kemudian dihubungkan dengan teori yang sudah dijelaskan sebelumnya. Selanjutnya siswa dituntut untuk menjelaskan lebih lanjut sampai pada tahap siswa bisa menemukan sebuah argumen. Dan pada tahap terakhir untuk menunjang berpikir kritis, maka siswa menyimpulkan dari hasil penemuannya sampai pada tahap menyelesaikan masalah.

Pengembangan E-LKPD berbasis android dengan problem based learning (PBL) ada 6 tahap untuk tingkatkan berpikir kritis yaitu mengenali permasalahan, mendeskripsikan tujuan, merancang dan meningkatkan artefak, menguji artefak, mengevaluasi hasil, serta mengevaluasi hasil pengujian (Sari \& Ma'rifah, 2020). Model pembelajaran dengan PBL bagi peserta didik dapat meningkatkan analisis dan interpretasi elemen berpikir kritis (Zhou, 2018). Penerapan PBL juga dapat meningkatkan kognitif tingkat tinggi (Salari, Roozbehi, Zarifi, \& Tarmizi, 2018), Kemudian penelitian oleh Shin \& Kim (2013) mengungkapkan bahwa PBL dapat meningkatkan kemampuan pemecahan masalah dan kepuasan siswa dalam proses pembelajaran.

Pengimplementasian problem based leraning $(P B L)$ mengacu pada paradigma berbasis masalah, berorientasi proses, terintegrasi disiplin, dan berpusat pada siswa dalam kelompok (Jun-F.W, dkk, 2017). 
1960 Pengembangan E-LKPD Berbasis Android dengan Model Pembelajaran Problem Based Learning (PBL) untuk Meningkatkan Berpikir Kritis Peserta Didik - Ika Melina Nur Fitriyah, Muhammad Abdul Ghofur DOI: https://doi.org/10.31004/edukatif.v3i5.718

PBL dengan bantuan aplikasi seluler memberikan efek yang positif pada siswa terhadap berpikir kritis (Ismail, Harun, Zakaria, \& Salleh, 2018). Pembelajaran dengan PBL menuntut siswa untuk memahami konsep yang dipelajari dengan melihat situasi atau permasalahan yang telah disajikan oleh guru pada awal pembelajaran dengan tujuan melatih siswa menyelesaikan suatu masalah (Utomo dalam Natalia, 2017). Sejalan dengan temuan Seibert (2021) bahwa strategi untuk meningkatkan berpikir kritis peserta didik yaitu menggunakan pembelajaran dengan model PBL.

Penelitian sebelumnya bahwa pemanfaatan teknologi dengan menggunakan LKPD bahwa hasil yang diperoleh adalah kategori baik dan layak untuk meningkatkan berpikir kritis (Melania, Pantjawati, \& Mulyanti, 2021). Dengan memberikan LKPD juga dapat memberikan dampak yang positif dalam belajar, sehingga dalam menyerap materi dapat tercipta pembelajaran yang menyenangkan dan menjadi bermakna (Celikler \& Aksan, 2012). LKPD ini dapat meningkatkan kualitas pembelajaran proses dan hasil pembelajaran yang baik (Dini Rahma Diani, Nurhayati, 2019) dan E-LKPD layak digunakan dalam pembelajaran berdasarkan aspek validitas, kepraktisan dan keefektifan bagi peserta didik (Fitriasari, 2021). Lembar kerja peserta didik berbasis android dikategorikan baik dan dapat meningkatkan respons peserta didik (Cholifah, 2016). LKPD dikatakan cukup efektif untuk meningkatkan berpikir kritis siswa dan berpengaruh secara signifikan terhadap uji t-test (Elfna \& sylfia, 2021). Pemberian lembar kerja juga dapat membiasakan peserta didik untuk berpikir secara ilmiah (Huda, 2015).

Berdasarkan permasalahan di atas, maka peneliti tertarik untuk mengembangkan sebuah bahan ajar dengan memanfaatkan teknologi yang sesuai, berupa Lembar kerja peserta didik ( LKPD ) dengan model problem based learning berbasis android. Bahan ajar yang disediakan berisi materi dan tugas - tugas untuk melatih siswa belajar secara mandiri, meningkatkan pemahaman siswa sekaligus keterampilan berpikir kritis. dengan adanya pembuatan E-LKPD, maka bahan ajar ini bisa digunakan sebagai pelengkap dalam belajar mereka. di dalam aplikasi tersebut terdapat instrumen musik, sehingga dalam belajar siswa tidak mengalami kebosanan. Musik sendiri berpengaruh terhadap tubuh dan pikiran untuk bekerja sama, karena bisa menciptakan keceriaan dan menyenangkan (Andita \& Desyandri, 2019). selain itu bahan ajar ini dirancang dengan tetap memberikan materi didalamnya, yang bertujuan agar peserta didik dapat belajar secara mandiri, Materi yang di sediakan tidak mudah hilang dan rusak, dan dapat menghemat waktu karena bisa digunakan di luar kelas serta dapat diunduh di smartphone. Terdapat fitur lembar kerja. hal ini siswa diminta untuk bediskusi dengan kelompoknya yang bisa dikerjakan secara bersama-sama. Fitur kuis berupa pilihan ganda yang dirancang untuk mengukur tingkat kognitif setiap individu masing - masing, dan digunakan untuk sarana pengulangan (rehearsal) untuk mengingat materi yang sudah di pelajari sebelumnya. E-LKPD menggunakan bantuan mobile learning yaitu untuk mempermudah siswa dalam belajar dan dapat mempercepat akses dalam memberikan informasi, sehingga dapat meningkatkan antusias siswa dalam belajar di tengah pandemi Bhati dan song (dalamAndita \& Desyandri, 2019).

Tujuan dari penelitian ini yaitu untuk mengetahui apakah terdapat pengaruh model pembelajaran problem based learning $(P B L)$ dalam berpikir kritis, dan apakah ada perbedaan antara kelas kontrol dan eksperimen dalam penggunaan media E-LKPD berbasis android dengan menggunakan model pembelajaran masing - masing.

\section{METODE PENELITIAN}

Jenis penelitian ini termasuk penelitian Research and Development $(R \& D)$. Menurut Sugiyono (2016) bahwa penelitian pengembangan yaitu menghasilkan sebuah produk dengan cara meneliti, merancang, membuat dan menguji validitas. Penelitian ini menggunakan model penelitian 4D (Four D models). Model 4D ini diadaptasi oleh Thiagarajan (dalam Kurniawan et al., 2017). Kemudian pengembangan 4D ini diambil dari 4 tahap yaitu Define, Design, Development dan Disseminate. 
1961 Pengembangan E-LKPD Berbasis Android dengan Model Pembelajaran Problem Based Learning (PBL) untuk Meningkatkan Berpikir Kritis Peserta Didik - Ika Melina Nur Fitriyah, Muhammad Abdul Ghofur DOI: https://doi.org/10.31004/edukatif.v3i5.718

Adapun prosedur pengembangan dalam penelitian ini yaitu tahap Define, yaitu tahap untuk merumuskan persyaratan dalam pembelajaran. Pada tahap ini peneliti akan mengumpulkan berbagai informasi tentang peserta didik atau permasalahan yang menjadi kendala, menentukan media yang dibutuhkan dalam pengembangan media, dan memberikan solusi yang efisien dalam pembelajaran. Tahap Design, yaitu tahap untuk merancang produk yang dihasilkan yang sudah dirancang sesuai dengan analisis define baik dari segi pemilihan media, format, dan pemilihan warna sesuai dengan keinginan peserta didik. Tahap Development, yaitu tahap untuk mewujudkan desain produk yang telah dirancang, selanjutnya divalidasi oleh para ahli, kemudian di uji kepada peserta didik secara terbatas. selain itu pada tahap ini juga terdapat revisi dari berbagai ahli di bidangnya sesuai dengan saran dan masukan. Tahap Disseminate, yaitu tahap penyebaran produk, yang bertujuan untuk menyebarluaskan produk setelah selesai dikembangkan oleh peneliti.

Subjek penelitian ini ialah pada kelas XI IPS 2 SMA Negeri 1 Bangil dengan jumlah sebanyak 36 peserta didik. Uji coba di lakukan dengan membagi 2 kelompok yang terdiri dari kelas kontrol dan kelas eksperimen secara acak. Hal ini di lakukan sekaligus untuk mengimplementasikan media yang telah dibuat. Kelas eksperimen di berikan perlakuan dengan menggunakan model pembelajaran PBL dengan E- LKPD berbasis android sedangkan untuk kelas kontrol di berikan dengan menggunakan metode konvensional.

Dalam penelitian ini, peneliti menggunakan One Group Pretes - Posttest Design yaitu sebuah desain yang akan diberikan pretest dan posttest setelah melakukan kegiatan pembelajaran guna mengetahui tingkat perbedaan sebelum dan sesudah setelah menggunakan E-LKPD berbasis android dengan model problem based learning. Instrumen untuk mengumpulkan data yaitu dengan menggunakan angket kepada siswa. Angket tersebut digunakan untuk mengetahui respons peserta didik setelah menggunakan media. Instrumen digunakan untuk di uji coba kepada siswa, yaitu dilakukan dengan menggunakan uji validitas dan reliabilitas. Uji validitas digunakan untuk mengetahui ketepatan alat dalam pengukuran, sedangkan uji reliabilitas untuk mengetahui konsistensi alat ukur, apakah alat ukur tersebut tetap konsisten apabila alat ukur tersebut dilakukan secara berulang (Nurmala dewi, 2018). Uji validitas menggunakan Product Moment, dan uji reliabilitas menggunakan Cornbach's Alpha.

Teknik analisis data digunakan untuk menganalisis data uji instrumen soal, hasil data penelitian, dan tanggapan siswa terkait penggunaan media. untuk mengetahui adanya kenaikan dalam berpikir kritis pada peserta didik, maka dilakukan Uji Normalitas, Uji T, dan Uji Gain Score. Uji Normalitas dilakukan untuk mengetahui apakah data tersebut terdistribusi normal atau tidak. Uji T dilakukan untuk mengetahui apakah terdapat perbandingan signifikan antara kelas kontrol dan eksperimen, dan uji Gain Score sendiri untuk mengetahui peningkatan pada ranah kognitif baik pada kelas kontrol maupun kelas eksperimen. Adapun penghitungan gain score dihitung sebagai berikut.

Gain -Score $=\frac{\text { Skor postest-Skor pretes }}{100-\text { Skor pretest }} \times 100 \%$

Setelah melakukan uji tes maka siswa harus mengisi angket yang berkaitan dengan media yang telah digunakan, adapun interpretasi siswa sebagai berikut.

Tabel 1. Interpretasi skor siswa

\begin{tabular}{ll}
\hline Persentase & Kriteria \\
\hline $0-20 \%$ & Tidak baik \\
$21-40 \%$ & Kurang baik \\
$41-60 \%$ & Cukup baik \\
$61-80 \%$ & Baik \\
$81-100$ & Sangat baik \\
\hline \multicolumn{2}{c}{ (Riduwan, 2015) }
\end{tabular}


1962 Pengembangan E-LKPD Berbasis Android dengan Model Pembelajaran Problem Based Learning (PBL) untuk Meningkatkan Berpikir Kritis Peserta Didik - Ika Melina Nur Fitriyah, Muhammad Abdul Ghofur DOI: https://doi.org/10.31004/edukatif.v3i5.718

\section{HASIL DAN PEMBAHASAN PENELITIAN}

Penelitian ini menggunakan tahap 4D yang terdiri dari Define, Design, Development, dan Disseminate. Tahap pertama dalam penelitian ini yaitu analisis terhadap peserta didik, yaitu tahap analisis peserta didik di kelas 11 IPS 2. Setiap peserta didik di dalam kelas memiliki karakteristik yang beragam. Pada saat pembelajaran dengan menggunakan zoom, ada beberapa peserta didik yang aktif saat bertanya dan menjawab pertanyaan dari guru. Selain itu juga ada siswa yang cenderung pasif saat pembelajaran dimulai. Pada kondisi pandemi saat ini, ada siswa yang melaksanakan proses pembelajaran di sekolah dan dilakukan secara daring di rumah. hal ini tentu akan menimbulkan perbedaan dalam menyampaikan materi meskipun dalam konteks yang sama.Karakteristik pada materi KD 3.4 dan 4.4 yaitu meliputi materi Indeks harga, Inflasi, Permintaan dan penawaran Uang. Materi ini sangat kompleks yaitu mencakup definisi istilah, menghitung, menghafal, dan menganalisis.

Hasil data sebanyak 36 peserta didik, diketahui ada beberapa indikator yang rendah, misalnya pada aplikasi penghitungan metode penghitungan Indeks harga, menghitung laju Inflasi, serta menganalisis dampak yang terjadi akibat Inflasi. Kemudian siswa masih rendah dalam menghubungkan teori yang sudah di jelaskan dengan contoh yang ada di kehidupan nyata. Sehingga akan menimbulkan permasalahan dalam belajar siswa nantinya.

Untuk mengatasi hal tersebut, maka disediakan sebuah bahan ajar berupa E-LKPD berbasis android yang bisa diunduh melalui handphone setiap individu. E-LKPD tersebut disediakan dengan sebuah studi kasus yang harus diselesaikan oleh peserta didik yaitu dengan menyediakan sebuah tabel berupa Indeks harga kebutuhan pokok. Siswa dituntut untuk bisa memperkirakan harga kebutuhan pokok beserta kuantitasnya. Selanjutnya siswa menghitung dengan menggunakan berbagai metode sesuai dengan perintah soal, dan membandingkan hasilnya. Selain itu di dalam E- LKPD ini siswa juga di sediakan berupa studi kasus yang harus dikerjakan secara berkelompok. Siswa diminta untuk berdiskusi untuk bersama - sama menyelesaikan dengan memberikan sebuah solusi pada contoh soal yang telah disediakan.

Tahap kedua yaitu tahap desain. Pada tahap ini yaitu merancang sebuah media sesuai dengan kebutuhan peserta didik, karena hanya beberapa siswa yang memiliki buku paket, maka di dalam E-LKPD ini disediakan sebuah materi di dalam aplikasi disertai contoh - contoh. Terdapat fitur lembar kerja yang harus diselesaikan oleh setiap kelompok maupun individu untuk mendukung pemahaman sekaligus cara berpikir kritis siswa dalam memecahkan soal.

Berdasarkan survei kepada peserta didik mengenai media, Bahwa siswa lebih menyukai warna biru. Warna biru ini memiliki arti kedalaman, kepercayaan, kesetiaan, ketulusan, kebijaksanaan, keyakinan, dan ketenangan (Ernawati, Akun, Shidarta, Besar, \& Pratama, 2014). Maka warna dalam E-LKPD ini menggunakan dominan berwarna biru. Sedangkan tema dari media ini yaitu pertokoan yang disertai grafik untuk melambangkan sebuah indeksnya. Adapun fitur tampilan halaman depan pada E- LKPD ini sebagai berikut 

untuk Meningkatkan Berpikir Kritis Peserta Didik - Ika Melina Nur Fitriyah, Muhammad Abdul Ghofur DOI: https://doi.org/10.31004/edukatif.v3i5.718

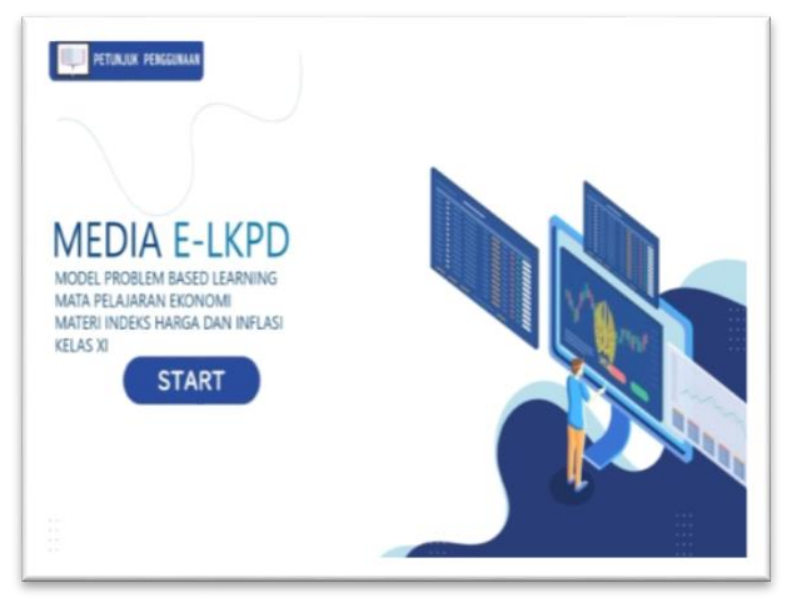

Gambar 1. Tampilan halaman depan (cover)

Setelah masuk pada tampilan halaman depan, maka siswa dianjurkan untuk menekan tombol start untuk masuk pada menu utama E-LKPD ini. Pada menu ini terdapat beberapa fitur pendukung di dalamnya. adapun gambarnya sebagai berikut .

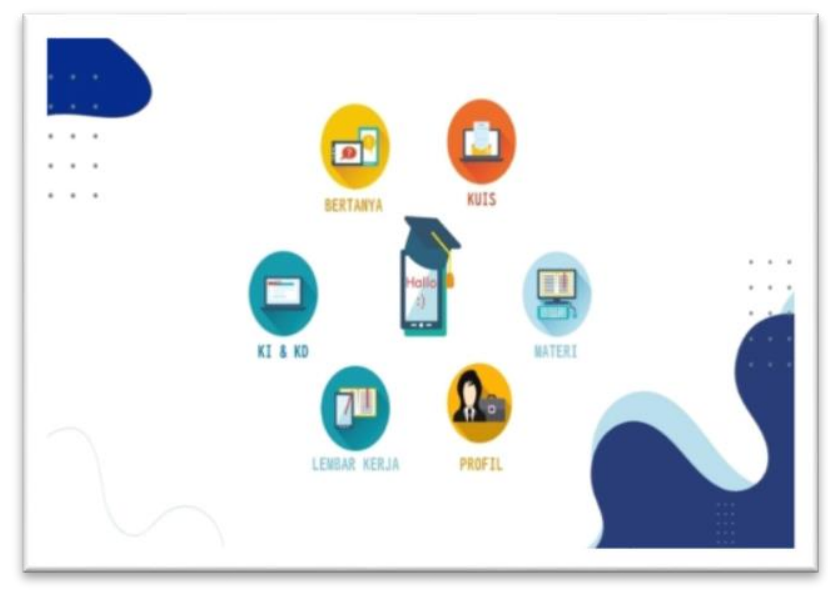

Gambar 2. Halaman menu utama

Halaman menu utama berisi tentang KI dan KD, materi, lembar kerja, kuis, latihan soal, bertanya, dan profil. Selanjutnya siswa bebas memilih menu apa yang diinginkan. Hal ini tentu akan memudahkan siswa dalam menggunakan aplikasi ini. Menu selanjutnya terdapat menu materi yang berisi materi Indeks harga, Inflasi, Permintaan dan Penawaran uang sesuai dengan standar kompetensi dan kompetensi dasar yang digunakan siswa sebagai acuan untuk menunjang proses belajar. sehingga dengan tersedianya materi di dalam aplikasi, maka siswa dapat membuka materi tersebut sewaktu - waktu bila diperlukan. 

untuk Meningkatkan Berpikir Kritis Peserta Didik - Ika Melina Nur Fitriyah, Muhammad Abdul Ghofur DOI: https://doi.org/10.31004/edukatif.v3i5.718

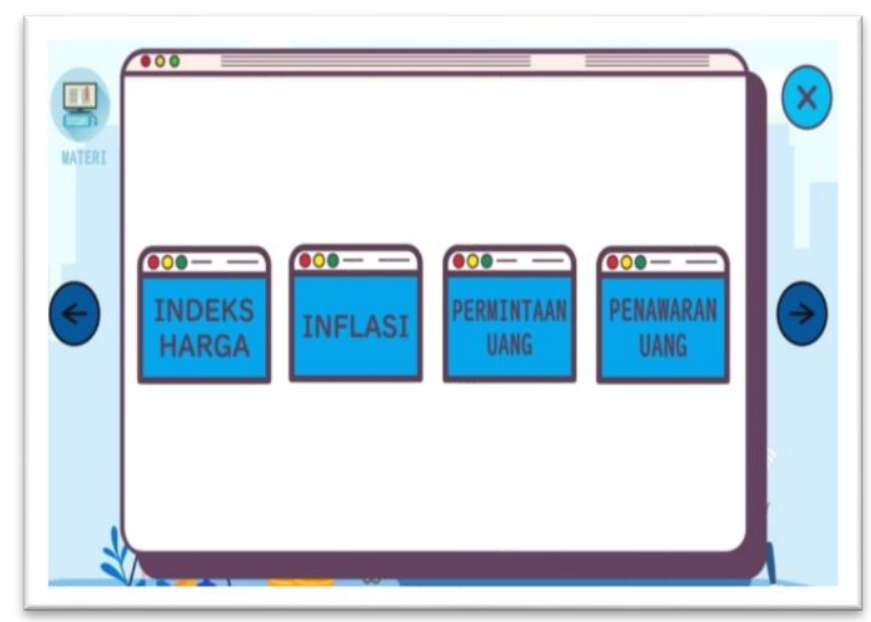

Gambar 3. Menu materi

Pada menu lembar kerja, siswa diminta untuk mengerjakan soal studi kasus berisi artikel yang harus dianalisis oleh siswa secara berkelompok. Lembar kerja yang tersedia memuat soal yang dikerjakan secara kelompok dan individu. Menu ini juga langsung terhubung dengan google formulir untuk mengirim hasil jawaban kepada guru, sekaligus memudahkan guru untuk mengoreksi jawaban dari peserta didik, sehingga guru bisa mengevaluasi hasil jawaban yang telah di kerjakan oleh siswa. Fitur ini dikembangkan dengan menyisipkan sintaks dari problem based learning seperti berorientasi pada masalah, dan dapat mempermudah siswa dalam menganalisis dan mengevaluasi pemecahan soal.

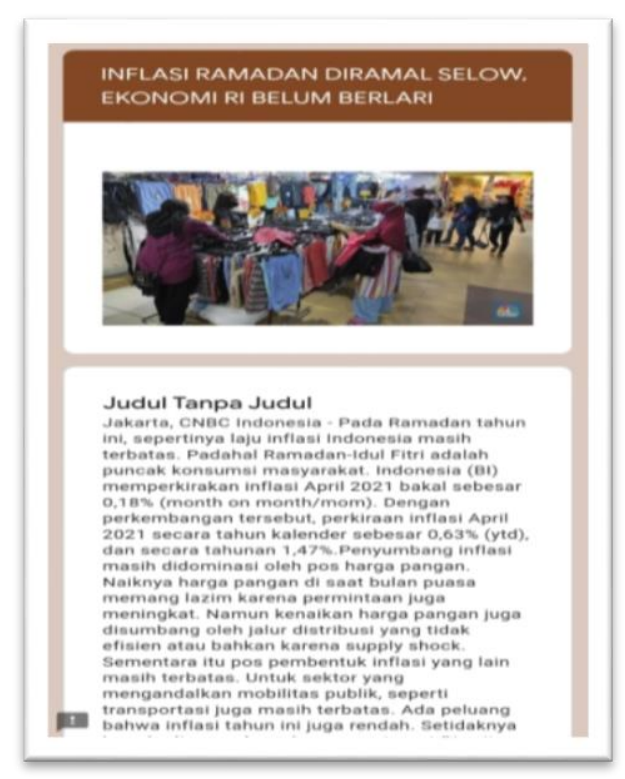

Gambar 4. Menu lembar kerja

Selanjutnya menu latihan soal yang berisi soal 60 soal pilihan ganda, soal ini digunakan untuk mengukur pemahaman siswa tentang materi yang dipelajari sebelumnya. Soal pilihan ganda disusun sesuai dengan kompetensi dasar. Setelah siswa mengerjakan soal tersebut, maka skor perolehan akan terlihat oleh setiap individu. 


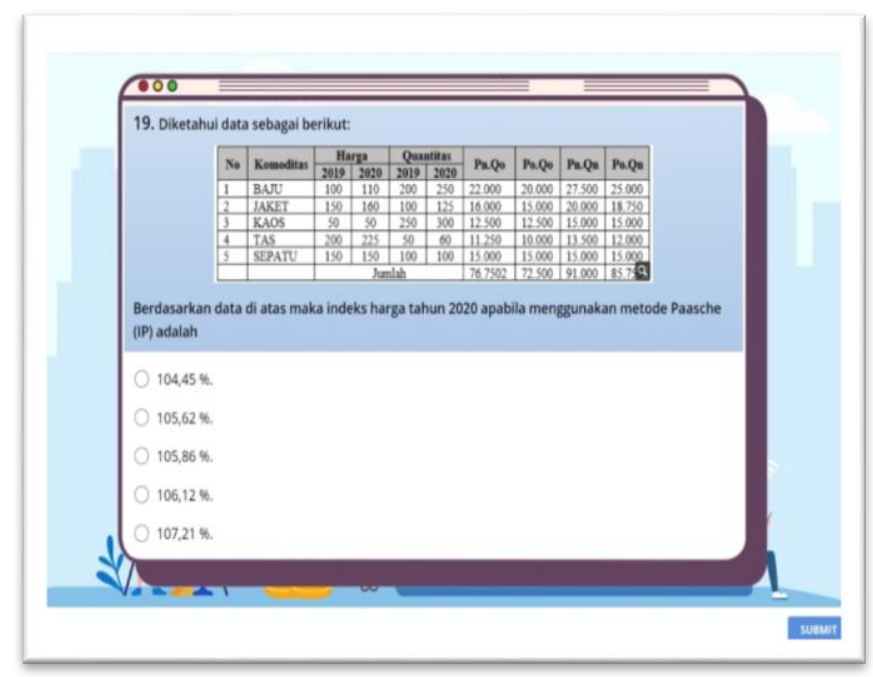

Gambar 5. Menu latihan soal

Tahap ketiga yaitu tahap pengembangan, tahap ini dilakukan untuk membuat produk yang sudah disusun sebelumnya. Tahap selanjutnya yaitu diuji coba kepada siswa secara terbatas kepada 36 siswa. Setelah melakukan uji coba produk E-LKPD berbasis android kepada peserta didik baik pada kelas eksperimen dan kelas kontrol, siswa diminta untuk mengisi angket tanggapan siswa setelah selesai menggunakan E-LKPD untuk mengetahui respons siswa terhadap penggunaan E-LKPD berbasis android pada saat pembelajaran. Hasil respons peserta didik sejumlah 36 siswa terhadap penggunaan E-LKPD berbasis android yaitu sebesar $84 \%$ dengan kriteria sangat baik. Hasil tersebut hampir sama dengan penelitian yang dilakukan oleh (Cholifah,2016) bahwa penggunaan E-LKPD berbasis android memiliki respons yang sangat baik bagi siswa untuk memudahkan dalam pembelajaran sebesar $85 \%$. Respons siswa akibat pembelajaran dengan menggunakan model problem based learning yang ada pada media menimbulkan ketertarikan pada peserta didik dalam pembelajaran (Imelda \& Anazelina, 2019). untuk meujudkan hal tersebut diperlukannya peran guru terhadap kemampuan berpikir kritis peserta didik dengan cara menyediakan suatu permasalahan kemudian di identifikasi oleh peserta didik. berdasarkan hasil yang diperoleh bahwa problem based learning mampu meningkatkan berpikir kritis atas dasar kerjasama dan diskusi baik oleh guru atau teman kelompok demi terwujudnya tujuan pembelajaran.

Untuk mengukur kemampuan siswa dalam berpikir kritis dengan penggunaan E-LKPD berbasis android, dilakukan pengujian instrumen soal pretest dan posttest, sebelum soal dibagikan kepada peserta didik, maka terlebih dahulu di uji dengan uji validitas dan reliabilitas yang terdiri dari 11 Indikator dengan 62 soal pilihan ganda. Soal tersebut disusun berdasarkan Kompetensi Inti (KI) dan Kompetensi dasar (KD). Adapun hasil dari uji validitas dan reliabilitas dilihat pada tabel 2 sebagai berikut.

Tabel 2. Validitas Butir soal

\begin{tabular}{l|c|c|c|}
\hline \multicolumn{1}{c|}{ Kriteria } & \multicolumn{1}{c|}{ Butir soal } & Jumlah & Persentase \\
\hline Valid & $1,3,4,5,7,8,11,12,13,14,15,16,17,18,19$, & & \\
& $20,21,22,24,25,27,28,29,30,33,34,36,3$ & 38 & $61,30 \%$ \\
Tidak Valid & $7,42,43,47,48,50,54,55,56,57,59,60,61$ & & \\
& $2,6,9,10,15,23,26,31,32,35,38,39,40,41$ & 24 & $38,70 \%$ \\
\hline & $, 44,45,46,49,51,52,53,58,62$ & & $100 \%$ \\
\hline
\end{tabular}


1966 Pengembangan E-LKPD Berbasis Android dengan Model Pembelajaran Problem Based Learning (PBL) untuk Meningkatkan Berpikir Kritis Peserta Didik - Ika Melina Nur Fitriyah, Muhammad Abdul Ghofur DOI: https://doi.org/10.31004/edukatif.v3i5.718

Tabel 3. Reliabilitas soal

\begin{tabular}{|l|l|}
\hline Cronbach's Alpha & N of items \\
\hline .983 & 62 \\
\hline
\end{tabular}

Dari hasil di atas, bahwa terdapat 38 soal yang valid, dan 24 soal yang dinyatakan tidak valid, maka soal yang tidak valid tersebut tidak digunakan. sehingga soal tes yang tidak valid harus dibuang dan beberapa diganti soal tes yang baru. soal yang baru tidak di validasi ulang karena adanya keterbatasan waktu dalam penelitian. kemudian soal yang dinyatakan valid tersebut langsung di uji reliabilitas. Pada tabel 3, menyatakan bahwa dari nilai Cronbach's Alpha sebesar 0,983 yaitu lebih signifikan dari 0,6. Maka butir soal dinyatakan dalam kriteria reliabel.

Selanjutnya untuk mengetahui peningkatan berpikir kritis baik dari kelas eksperimen dan kelas kontrol yaitu dengan menggunakan uji gain score. Hasil uji gain score bahwa pada kelas eksperimen yang terdiri 18 siswa. Terdapat 1 anak yang memiliki kriteria tinggi, 13 anak yang memiliki kriteria sedang, dan 4 anak yang memiliki kriteria rendah. Sedangkan untuk kelas kontrol terdiri atas 18 siswa. Terdapat 1 anak dengan kriteria tinggi, 9 anak dengan kriteria sedang, dan 8 anak dengan kriteria rendah. Hasil tersebut diperoleh dengan dengan melihat hasil dari kedua tes yang telah dilakukan pada kelas eksperimen dan kelas kontrol.

Berdasarkan hasil data dari keseluruhan bahwa kelas eksperimen menggunakan E-LKPD berbasis android dengan model pembelajaran problem based learning mengalami peningkatan berpikir kritis sebesar 77.83, yang diikuti perolehan hasil uji gain score memperoleh skor rata- rata $0.42>0.3$ dengan kriteria sedang. Sedangkan untuk kelas kontrol menggunakan E- LKPD dengan metode konvensional juga mengalami peningkatan berpikir kritis sebesar 69.16, yang di ikuti dengan perolehan uji gain score sebesar $0.27<0.3$, sehingga masuk dalam kriteria rendah. Adapun hasil uji gain score terlihat pada tabel 4.

Tabel 4. Hasil gain-score

\begin{tabular}{l|l|l|l|}
\hline Kelas & Pretest & Postest & Ngain score \\
\hline Eksperimen & 1.110 & 1.401 & 7.56 \\
Rata - rata & 61,6 & 77,83 & 0,42 \\
Kontrol & 1.011 & 1.245 & 4.79 \\
Rata-rata & 56,1 & 69,16 & 0,27 \\
\hline
\end{tabular}

Kemudian untuk mengetahui apakah data penelitian terdistribusi normal atau tidak, maka dilakukan uji normalitas baik pada kelas eksperimen dan kelas kontrol. Uji normalitas dilakukan dengan menggunakan Kolmogorov-Smirnov. Jika nilai sig > 0,05, maka data tersebut dikatakan terdistribusi normal, namun jika nilai sig $<0,05$, maka data dikatakan tidak terdistribusi secara normal.

Tabel 5. Uji Normalitas

\begin{tabular}{|c|c|c|c|c|c|c|c|}
\hline & \multirow[b]{2}{*}{ Kelas } & \multicolumn{3}{|c|}{ Kolmogorov-Smirnov ${ }^{a}$} & \multicolumn{3}{|c|}{ Shapiro-Wilk } \\
\hline & & $\begin{array}{l}\text { Statisti } \\
\text { c }\end{array}$ & $D f$ & Sig. & Statistic & $d f$ & Sig. \\
\hline $\begin{array}{l}\text { Hasil } \\
\text { Berfikir }\end{array}$ & $\begin{array}{l}\text { Pre-test } \\
\text { (PBL) }\end{array}$ & .147 & 18 & $.200^{*}$ & .920 & 18 & .131 \\
\hline Kritis & $\begin{array}{l}\text { Post-test Eksperimen } \\
\text { (PBL) }\end{array}$ & .129 & 18 & $.200^{*}$ & .944 & 18 & .345 \\
\hline & Pre-test Kontrol & .158 & 18 & $.200^{*}$ & .937 & 18 & .260 \\
\hline & Post-test Kontrol & .170 & 18 & .183 & .933 & 18 & .219 \\
\hline
\end{tabular}


1967 Pengembangan E-LKPD Berbasis Android dengan Model Pembelajaran Problem Based Learning (PBL) untuk Meningkatkan Berpikir Kritis Peserta Didik - Ika Melina Nur Fitriyah, Muhammad Abdul Ghofur DOI: https://doi.org/10.31004/edukatif.v3i5.718

Berdasarkan data uji normalitas pada gambar tabel 6, dapat diketahui bahwa data kelas eksperimen dan kontrol memiliki nilai sig 0.200 dengan memenuhi kriteria bahwa nilai $\alpha>0.05$, sehingga data pretest dan posttest dikatakan dalam kriteria terdistribusi secara normal.

Tabel 6. Uji T

\begin{tabular}{|c|c|c|c|c|c|c|c|c|c|}
\hline \multicolumn{10}{|c|}{ Paired Samples Test } \\
\hline & & \multicolumn{5}{|c|}{ Paired Differences } & & \multirow[b]{2}{*}{$d f$} & \multirow[b]{2}{*}{$\begin{array}{l}\text { Sig. } \\
\text { tailed) }\end{array}$} \\
\hline & & Mean & $\begin{array}{l}\text { Std. } \\
\text { Deviatio } \\
n\end{array}$ & \begin{tabular}{|l} 
Std. \\
Error \\
Mean
\end{tabular} & $\begin{array}{l}95 \% \quad C \\
\text { Interval } \\
\text { Differenc } \\
\text { Lower }\end{array}$ & $\begin{array}{l}\text { onfidence } \\
\text { of the } \\
\text { Upper }\end{array}$ & & & \\
\hline Pair 1 & $\begin{array}{l}\text { PreEksperimen } \\
\text { PostEksperimen }\end{array}$ & -16.167 & 7.801 & 1.839 & -20.046 & -12.287 & -8.793 & 17 & .000 \\
\hline Pair 2 & $\begin{array}{l}\text { PreKontrol } \\
\text { PostKontrol }\end{array}$ & -13.000 & 10.533 & 2.483 & -18.238 & -7.762 & -5.236 & 17 & .000 \\
\hline
\end{tabular}

Selanjutnya yaitu dengan uji t, syarat dilakukan uji t bahwa pada uji normalitas dengan menggunakan Kolmogorov Smirnov yaitu data harus terdistribusi secara normal. uji t sendiri dilakukan untuk mengetahui apakah terdapat perbedaan hasil antara hasil pretest dan posttest dalam penggunaan E-LKPD berbasis android pada kelas eksperimen dan kontrol. Jika nilai sig $<0.05$, maka terdapat perbedaan antara hasil pretest dan posttest, namun jika nila sig $>0.05$ maka data tersebut tidak terdapat perbedaan dari hasil pretest dan posttest.

Dari data hasil uji t yang terlihat pada gambar tabel 7 , bahwa data pretest dan posttest pada kelas eksperimen dan kelas kontrol adalah nilai Sig. (2-tailed) sebesar 0.00 lebih kecil dari 0.05, Maka $\mathrm{H}_{0}$ ditolak dan menerima $\mathrm{H}_{1}$. yang artinya bahwa hasil data baik pada kelas eksperimen dan kelas kontrol terdapat perbedaan yang signifikan dari hasil belajar saat pretest dan posttest dengan model pembelajaran yang digunakan pada masing - masing kelas. Peningkatan berpikir kritis dengan menggunakan E-LKPD berbasis android dengan problem based learning meningkat dibandingkan dengan menggunakan metode konvensional dalam memecahkan masalah.

Hasil ini terlihat dengan adanya peningkatan dalam belajar dari segi berpikir kritis siswa oleh penelitian (Ardiyanti, 2016) bahwa dengan menerapkan model pembelajaran problem based learning (PBL), cara berpikir siswa akan mengalami peningkatan. Penerapan kelas eksperimen dengan model pembelajaran Problem Based Learning (PBL) ini dapat melatih keterampilan berpikir kritis, penggunaan model pembelajaran tersebut akan mengakibatkan siswa lebih aktif dan menantang dalam pemecahan masalah pada soal, serta dapat mengakibatkan siswa dalam proses pembelajaran tidak bergantung pada guru, melainkan bisa diskusi antar teman. Berbeda dengan kelas eksperimen, bahwa pada kelas kontrol dilakukan dengan cara tradisional atau konvensional, yaitu mendengarkan penjelasan guru, kemudian berlatih untuk mengerjakan soal latihan yang ada di buku. Hasil penelitian pada kelas kontrol menunjukkan bahwa siswa belum terlatih secara runtut, dan kurang termotivasi. Maka pembelajaran dengan menerapkan problem based learning sangat cocok untuk materi ekonomi yaitu Indeks harga dan Inflasi khususnya dalam pemecahan masalah dan berpikir kritis.

Hal ini sejalan dengan penelitian oleh (Herzon, Budijanto, \& Utomo, 2018) bahwa dengan model pembelajaran problem based learning ( $P B L$ ) efektif dan cocok digunakan dalam proses pembelajaran yang dapat meningkatkan keterampilan berpikir kritis, kemudian diperkuat penelitian oleh (Herzon et al., 2018) yang mengatakan model pembelajaran problem based learning $(P B L)$ memiliki dampak yang positif terhadap berpikir kritis peserta didik. hal ini terlihat adanya keseriusan siswa dalam berdiskusi untuk menyelesaikan soal cerita dengan kelompoknya dan dapat meningkatkan siswa untuk termotivasi dalam belajar. Penerapan pembelajaran dengan berbasis masalah dapat mengoptimalkan pengalaman balajar seperti siswa mendapat 
1968 Pengembangan E-LKPD Berbasis Android dengan Model Pembelajaran Problem Based Learning (PBL) untuk Meningkatkan Berpikir Kritis Peserta Didik - Ika Melina Nur Fitriyah, Muhammad Abdul Ghofur DOI: https://doi.org/10.31004/edukatif.v3i5.718

pengalaman dalam hal memecahkan studi kasus, mencatat data, mencari sumber yang relevan, dan mempresentasikan hasil diskusi dengan kelompoknya.

Temuan dengan adanya peningkatan dalam berpikir kritis yaitu pada saat mengikuti pembelajaran, ada beberapa siswa yang cenderung pasif dan mencoba aktif dalam suasana diskusi. Saat guru memberikan stimulus kepada peserta didik dengan menambah poin apabila mampu mengungkapkan sebuah pendapatnya sendiri, hal ini bertujuan untuk membuat siswa lebih responsif dalam mengikuti pelajaran. Sehingga dalam suasana ini guru yang mengendalikan suasana kelas daring. tentunya dalam hal ini akan menyebabkan siswa yang biasanya hanya menerima materi yang telah disampaikan oleh guru, setelah model pembelajaran tersebut diterapkan maka siswa cenderung lebih selektif dalam mengungkapkan sebuah pendapatnya terutama pada solusi-solusi yang dihubungkan pada lingkungan sekitar. dalam jangka panjang berdampak pada kemampuan berpikir kritis siswa karena akan banyak pengetahuan yang diperoleh dengan bekerja sama dengan teman sebayanya.

Berpartisipasi dengan kelompoknya saat berdiskusi akan menciptakan solusi dari masaah - masalah yang dihadapi. Solusi yang diberikan sangat inovatif, yang merupakan pengalaman belajar bagi siswa. sehingga siswa bisa saja memberikan solusi yang kreatif berdasarkan pemikiran yang dimiliki untuk menunjang cara berpikir ktitis. Pemikiran yang kreatif dan kritis akan menghasilkan inovasi dan pendidikan berkualitas secara berkelanjutan (Sari \& Ma'rifah, 2020). keterbatasan dalam temuan ini bahwa dalam pengimplementasikan problem based learning di tengah pandemi sulit untuk dilakukan, karena siswa harus berdiskusi dengan temannya menggunakan handphone. selain itu guru tidak bisa mengarahkan siswa sepenuhnya dalam memecahkan masalah karena keterbatasan jam yang disediakan oleh sekolah. Namun dengan adanya penelitian ini bahwa pada saat pandemi saat ini problem based learning masih bisa dilakukan dengan menggunakan bahan ajar yang manarik, yang dikemas dengan berbagai fitur sesuai kebutuhan peserta didik, untuk memacu semangat dalam belajar, dan bisa berlatih secara mandiri dalam meningkatkan berpikir kritis dan pengetahuannya terhadap materi yang dipelajarinya. temuan ini juga diperkuat oleh penelitian Mulyani (2020) bahwa model pembelajaran problem based learning efektif dilakukan meskipun dalam keadaan daring. dan diperkuat oleh Sefriani \& Sepriana (2020) bahwa dengan bantuan berbasis digital dapat melatih siswa secara mandiri dan bersungguh - sungguh dalam mengikuti proses pembelajaran dengan kondisi daring, sehingga kemampuan dalam berpikir kritis dapat meningkat.

Tahap keempat yaitu penyebaran, tahap ini dilakukan untuk memperluas E- LKPD berbasis android. Penyebaran aplikasi ini masih disebarkan melalui aplikasi whatsapp grup kepada peserta didik. Sehingga hanya siswa yang tergabung dalam grup whatsapp yang bisa mengunduh aplikasi tersebut. Dalam pembuatan aplikasi ini tentunya ada kelebihan dan kelemahan. kelebihan dari E- LKPD ini yaitu berbasis mobile learning, sehingga bisa di unduh melalui smartphone masing-masing. Bersifat interaktif, yaitu siswa bisa menentukan arah pembelajaran sesuai dengan keinginannya dalam belajar. Terdapat fitur latihan soal, yang bertujuan agar siswa bisa lebih mudah mengukur kemampuannya sendiri setelah mempelajari materi yang ada di dalam aplikasi tersebut. Kelemahannya dari aplikasi tersebut yaitu e-LKPD ini masih dibatasi oleh pengembang, belum memuat video yang berhubungan dengan materi yang ada di dalamnya, Serta hanya bisa dipakai oleh smartphone yang berbasis android, selain itu lembar kerja yang langsung terhubung dengan google formulir, maka siswa harus mengerjakan secara sistematis untuk mencapai tahap berikutnya.

\section{KESIMPULAN}

Kesimpulan dari penelitian ini yaitu pada kelas eksperimen mengalami peningkatan dalam berpikir kritis dan hasil gain score dengan kriteria sedang. sedangkan pada kelas kontrol dalam berpikir kritis juga meningkat, yang diikuti peroleh gain score dengan kriteri rendah. untuk hasil uji t bahwa pada kelas ekperimen dan kelas kontrol terdapat perbedaan dari hasil pretest dan posttest. Hasil tanggapan siswa terkait 
1969 Pengembangan E-LKPD Berbasis Android dengan Model Pembelajaran Problem Based Learning (PBL) untuk Meningkatkan Berpikir Kritis Peserta Didik - Ika Melina Nur Fitriyah, Muhammad Abdul Ghofur DOI: https://doi.org/10.31004/edukatif.v3i5.718

penggunaan E-LKPD berbasis android sebesar $85 \%$ dengan kriteria sangat baik, sehingga bisa membantu siswa untuk mempermudah dalam belajar secara mandiri. Saran selanjutnya yaitu diharapkan bagi peneliti berikutnya untuk mengembangkan fitur - fitur yang ada dalam bahan ajar E-LKPD berbasis android ini, yang di sajikan dengan kebutuhan siswa sesuai dengan karakteristik materi yang diajarkan, Serta produk diujikan lebih luas lagi, supaya mendapat masukan lebih banyak yang dapat bermanfaat bagi penggunanya.

\section{DAFTAR PUSTAKA}

Andita, C. D., \& Desyandri, D. (2019). Pengaruh Penggunaan Musik Terhadap Konsentrasi Belajar Anak Sekolah Dasar. Edukatif: Jurnal Ilmu Pendidikan, 1(3), 205-209. https://doi.org/10.31004/edukatif.v1i3.50

Ardiyanti, Y., Studi, P., Matematika, P., \& Karawang, U. S. (2016). Berpikir kritis siswa dalam pembelajaran berbasis masalah berbantuan kunci determinasi. 5(2), 193-202.

Assegaff, A., \& Sontani, U. T. (2016). Upaya Meningkatkan Kemampuan Berfikir Analitis Melalui Model Problem Based Learning (Pbl). Jurnal Pendidikan Manajemen Perkantoran, 1(1), 38. https://doi.org/10.17509/jpm.v1i1.3263

Celikler, D., \& Aksan, Z. (2012). The Effect of the Use of Worksheets About Aqueous Solution Reactions on Pre-service Elementary Science Teachers' Academic Success. Procedia - Social and Behavioral Sciences, 46, 4611-4614. https://doi.org/10.1016/j.sbspro.2012.06.306

CHOLIFAH, R. (2016). Pembuatan Lembar Kerja Siswa Berbasis Android Pada Mata Pelajaran Produktif Multimedia Kelas XI Di SMKN 1 Driyorejo. It-Edu, I(2).

Dini Rahma Diani, Nurhayati, D. S. (2019). Pengembangan Lembar Kerja Peserta Didik (LKPD) Menulis Cerpen Berbasis Aplikasi Android. Jurnal Bahasa, Sastra, Dan Pengajarannya, 7, 2.

Ernawati, E., Akun, Shidarta, Besar, \& Pratama, B. (2014). Humaniora: Language, People, Art, and Communication Studies. 5(1).

Fatriani, E., \& Sukidjo, S. (2018). Efektivitas metode problem based learning ditinjau dari kemampuan berpikir kritis dan sikap sosial siswa. SOCIA: Jurnal Ilmu-Ilmu Sosial, 15(1), 11-26. https://doi.org/10.21831/socia.v15i1.20089

Furman Shaharabani, Y., \& Yarden, A. (2019). Toward narrowing the theory-practice gap: characterizing evidence from in-service biology teachers' questions asked during an academic course. International Journal of STEM Education, 6(1). https://doi.org/10.1186/s40594-019-0174-3

Herzon, H. H., Budijanto, \& Utomo, D. H. (2018). Pengaruh problem-based learning (pbl) terhadap keterampilan berpikir kritis. Jurnal Pendidikan: Teori, Penelitian, Dan Pengembangan, 3(1), 42-46. Retrieved from http://journal.um.ac.id/index.php/jptpp/

Huda, M., \& Pd, M. (2015). Pengembangan Lembar Kerja Eksplorasi Mata Pelajaran Matematika Berbasis Android. 622-628.

Imelda, \& Anazelina, D. (2019). Respon siswa terhadap pembelajaran problem based learning dalam meningkatkan Higher Order Thinking Skill. Jurnal of Mathematics Education and Science, 5(1), 11-19.

Ismail, N. S., Harun, J., Zakaria, M. A. Z. M., \& Salleh, S. M. (2018). The effect of Mobile problem-based learning application DicScience PBL on students' critical thinking. Thinking Skills and Creativity, 28, 177-195. https://doi.org/10.1016/j.tsc.2018.04.002

Jumaat, N. F., \& Tasir, Z. (2014). Instructional scaffolding in online learning environment: A meta-analysis. Proceedings - 2014 International Conference on Teaching and Learning in Computing and Engineering, LATICE 2014, 74-77. https://doi.org/10.1109/LaTiCE.2014.22

Jun-fengWANG*, Shi-qi LI, Yan FU, Shi-ping LIU, H. J. (2017). Proceedings of the 23rd International 
1970 Pengembangan E-LKPD Berbasis Android dengan Model Pembelajaran Problem Based Learning (PBL) untuk Meningkatkan Berpikir Kritis Peserta Didik - Ika Melina Nur Fitriyah, Muhammad Abdul Ghofur DOI: https://doi.org/10.31004/edukatif.v3i5.718

Conference on Industrial Engineering and Engineering Management 2016. Proceedings of the 23rd International Conference on Industrial Engineering and Engineering Management 2016, 23-24. https://doi.org/10.2991/978-94-6239-255-7

Kurniawan, D., Dewi, S. V., Pendidikan, J., Fakultas, M., Dan, K., Pendidikan, I., \& Siliwangi, U. (2017). Pengembangan Perangkat Pembelajaran Dengan Media Screencast- O-Matic Mata Kuliah Kalkulus 2 Menggunakan Model 4-D Thiagarajan. Jurnal Siliwangi, 3(1).

Melania, I., Pantjawati, A. B., \& Mulyanti, B. (2021). Development of Student Worksheet for Infrared Technology Material Using Project Based Learning and Science Technology Engineering Mathematics Learning Model. 520(Tvet 2020), 240-243.

Mulyani, S. (2020). Penerapan Metode Pembelajaran Problem Based Learning Guna Meningkatkan Hasil Belajar IPA Di Masa Pandemi Covid 19. Navigation Physics : Journal of Physics Education, 2(2), 84-89. https://doi.org/10.30998/npjpe.v2i2.489

Natalia, D. S. (2017). Penerapan Model Pembelajaran Berbasis Masalah Dengan Bantuan Media Video Untuk Meningkatkan Keterampilan Menulis Teks Eksposisi Siswa. Jurnal Penelitian Dan Pengembangan Pendidikan, 1(2), 123-133. https://doi.org/10.23887/jppp.v1i2.12625

Nurmala dewi, dian A, N. (2018). Uji Validitas Dan Reliabilitas. Jurnal Tarbiyah: Jurnal Ilmiah Kependidikan, 7(1), 17-23.

Pada, T., Fotosintesis, M., \& Xii, K. (2021). BioEdu. 10(3), 510-522.

Patonah, S. (2014). Elemen bernalar tujuan pada pembelajaran ipa melalui pendekatan metakognitif siswa SMP. Jurnal Pendidikan IPA Indonesia, 3(2), 128-133. https://doi.org/10.15294/jpii.v3i2.3111

Riduwan. (2015). Skala Pengukuran Variabel - Variabel Penelitian. Bandung: Alfabeta.

Salari, M., Roozbehi, A., Zarifi, A., \& Tarmizi, R. A. (2018). Pure PBL, Hybrid PBL and Lecturing: Which one is more effective in developing cognitive skills of undergraduate students in pediatric nursing course? BMC Medical Education, 18(1), 1-15. https://doi.org/10.1186/s12909-018-1305-0

Sari, W. P., \& Ma'rifah, D. R. (2020). Pengembangan Lkpd Mobile Learning Berbasis Android Dengan Pbl Untuk Meningkatkan Critical Thinking Materi Lingkungan. Jurnal Pendidikan Biologi, 11(2), 49. https://doi.org/10.17977/um052v11i2p49-58

Sefriani, R., \& Sepriana, R. (2020). Pengembangan Media E-Learning Berbasis Schoology pada Pembelajaran Kurikulum Pendidikan Teknologi dan Kejuruan. Edukatif: Jurnal Ilmu Pendidikan, 2, 8-14.

Seibert, S. A. (2021). Problem-based learning: A strategy to foster generation Z's critical thinking and perseverance. Teaching and Learning in Nursing, 16(1), 85-88. https://doi.org/10.1016/j.teln.2020.09.002

Shin, I. S., \& Kim, J. H. (2013). The effect of problem-based learning in nursing education: A meta-analysis. Advances in Health Sciences Education, 18(5), 1103-1120. https://doi.org/10.1007/s10459-012-9436-2

Sugiyono. (2016). Metodologi Penelitian Pendidikan. Bandung: Alfabeta.

Warsita, B. (2018). Mobile Learning Sebagai Model Pembelajaran Yang Efektif Dan Inovatif. Jurnal Teknodik, 14(1), 62. https://doi.org/10.32550/teknodik.v14i1.452

Zhou, Z. (2018). An Empirical Study on the Influence of PBL Teaching Model on College Students' Critical Thinking Ability. English Language Teaching, 11(4), 15. https://doi.org/10.5539/elt.v11n4p15 